\title{
The Implementation of Care for the Environment Character through Ro'an Culture in Miftahu Rahmatillah Islamic Boarding School Patemon Village
}

\author{
Ferani Mulianingsih $^{1}$, Arif Taufiq Dani Abdillah ${ }^{2}$ \\ \{feranigeographer@mail.unnes.ac.id ${ }^{1}$, danielsaolendra@gmail.com $\left.{ }^{2}\right\}$ \\ ${ }^{1}$ Universitas Negeri Semarang, Indonesia \\ ${ }^{2}$ PPPPTK Penjas dan BK, Indonesia
}

\begin{abstract}
Nowadays, human awareness of the environment is decreasing. That is because of the lack of planting characters in daily life. The national commitment regarding the need for character education is imperatively stated in Law Number 20 of 2003 concerning the National Education System. The role of education is needed very much in the internalization of character values both formal education such as school and non-formal education such as Islamic boarding school. Miftahu Rahmatillah Islamic Boarding School is a non-formal education institutions in Gunungpati District, Semarang City. This Islamic boarding school is located close to the highway. So it takes extra care in maintaining the cleanliness of this boarding school environment. The existence of a community service program or often known as the ro'an in this Islamic boarding school certainly has a big contribution in maintaining the beauty and cleanliness of the boarding school environment. The objectives of this study are: to explain the role of santri at Miftahu Rahmatillah Islamic Boarding School in maintaining the cleanliness of the boarding school environment. Knowing the influence of foreign workers on the Indonesian economy, explaining the supporting factors and inhibitors of Miftahu Rahmatillah Islamic Boarding School in applying a caring attitude towards the environment, explaining the implementation of the Islamic boarding school culture towards the behavior of the santri of Miftahu Rahmatillah Islamic Boarding School in maintaining environmental care. The type of research used is qualitative. The subjects in this study were students from Miftahu Rahmatillah Islamic Boarding School. The field research result can be concluded that the development of environmental caring characters through the tradition of the ro'an can be done through a variety of custom activities carried out at ro'an time.
\end{abstract}

Keywords: Ro'an Culture, Care, Environment, Character.

\section{Introduction}

Nowdays, human awareness of the environment is decreasing. That is because of the lack of planting characters in daily life. The national commitment regarding the need for character education is impretively stated in Law Number 20 of 2003 concerning the National Education System. In article 3, it is stated that National Education has the fuction of developing capabilities and forming dignified national character and civilization in order to educate the nation's life, aiming at the potential of students to become human beings who have faith and 
knowledge, are competent, creative, independent, and become democratic citizens and responsible [1].

Islamic boarding school is one of the non-formal education in Indonesia which is considered the oldest education system. Islamic boarding school education was born long before education with the school system born. This Islamic boarding school grew as an embodiment of the strategy of Muslims to maintain its existence againts the influence of western colonialism and became an alternative to anticipate the fullness of the mosque which was then used as a center of teaching and learning activities of Muslims [2].

In its journey, Islamic boarding school always experience dynamics that never stop, in line with the social changes that occur. As the main axis of the social, cultural and religious dynamics of the traditional Islamic community, Islamic boarding schools have formed a subculture that can be said to be an Islamic boarding school society socio-anthropologically. This is shown in the two main functions possessed by Islamic boarding schools, namely as an educational institution that requires an education system and teaching and learning patterns that are typical of Islamic boarding schools. Besides that, the function of Islamic boarding schools also as dakwah institutions that always internalize Islamic values in the Islamic boarding schools community and the community outside of Islamic boarding schools. Santri who live in Islamic boarding schools are required to have caring attitude towards the environment.

As an original institution of Nusantara products Islamic boarding schools show the characteristic of "mutual cooperation" which is part of the original tradition of Indonesian society which has begun to disappear due to eroded by outside cultures. The erosion of indigenous cultures of Indonesia is one of the effects of the ferocity of globalization. Islamic boarding schools with their collective way of life are one of the manifestations of the spirit and tradition of mutual cooperation in the community. Values like al-ukhuwah (brotherhood), at-ta'awun (help), alittihad (unity), thalab al-ilm (studying), al-ikhlas (sincere), aljihad (struggle), al-thaah ( obeying God, Apostles and Leaders) helped support the existence of Islamic boarding schools [3].

Miftahu Rahmatillah Islamic Boarding School is a non-formal education institutions in Gunungpati District, Semarang City. This Islamic boarding school is located close to the highway. So it takes extra care in maintaining the cleanliness of this boarding school environment. The existence of a community service program or often known as the ro'an in this Islamic boarding school certainly has a big contribution in maintaining the beauty and cleanliness of the boarding school environment.

Almost all Islamic boarding schools in Indonesia recognize the term ro'an (community service), which is the activity of mobilizing all pesantren to clean the environment around the pesantren with the aim of maintaining environmental cleanliness. An illustration of the ro'an activities at the Miftahu Rahmatillah Islamic Boarding School is that there is a regular ro'an schedule made by the Hygiene Department. The roan schedule at the Miftahu Rahmatillah Islamic Boarding School is divided into 2 weekly pickets every Sunday morning and daily pick-ups that are held every day. The technical implementation of the ro'an is divided into rooms with certain ro rations such as cleaning bathrooms, mosques, clothes lines and so on.

In connection with this matter, the writer is interested in conducting research with the title "The Implementation of Care for the Environment Character Through Ro'an Culture In Miftahu Rahmatillah Islamic Boarding School Patemon Gunungpati Semarang”. 


\section{Research Method}

\subsection{Types of Research}

This type of research uses qualitative descriptive research methods, namely research that uses as much data collection or information about the symptoms that exist in the research area. Thus the purpose of this qualitative research is to know and observe the development of environmental care characters through the tradition of ro'an. The qualitative approach used is a case study, to find out more deeply and in detail about a problem or phenomenon to be investigated.

\subsection{Research Setting}

This qualitative descriptive study took place at the Miftahu Rahmatillah Islamic Boarding School in Patemon Gunungpati village, Semarang. This qualitative descriptive study was conducted during April 2019. The subjects in this study were students from the Miftahu Rahmatillah Islamic Boarding School.

\section{Results and Discussion}

The tradition of cleaning in the Islamic boarding school is often referred to as the Ro'an tradition. Ro'an starts with the word tabarrukan, which is abbreviated as rukan, then becomes ro'an. Ro'an is something that is customary and inherent in the identity of the Islamic boarding school. Every student is burdened for ro'an, at least is cleaning his/her own room. Besides the cleanliness of Islamic teachings, also cleanliness is a doctor's recommendation and of course the benefits of cleanliness for each of them.

This is also found in the Miftahu Rahmatillah Islamic Boarding School. In this case Ro'an does not only carry out activities in terms of cleanliness, but also includes mutual cooperation activities in all respects, but roans are more likely to be interpreted as cleaning activities by being carried out together. Ro'an in this Islamic boarding school itself has existed since the first time the Islamic boarding school stood with the first initiation from the caregiver, then with the development of the Islamic boarding school, it already has its own management structure managed by Santri. So until now in the Miftahu Rahmatillah Islamic Boarding School, ro'an is arranged by boarding school boarders.

Ro'an activities are held once a week by involving all santri in Islamic boarding school without exception, but based on the results of interviews with the head of the village of the Miftahu Rahmatillah Islamic Boarding School, although ro'an is attended by all santri but there is still a ro'an coordinator who is in charge of activities the weekly and scheduled.

In the implementation of environmental hygiene activities carried out with several things, namely first cleaning all the rooms in the Islamic boarding school with members of the room as cleaning officers, then proceed with cleaning the front porch of the room. After all is done, all santri are diverted to clean the mosque of Islamic boarding school, the yard of the ustadz or kyai caregiver of the Islamic boarding school and also clean the bathroom. Of course, these tasks are divided into each group of santri, both administrators and santri who usually take part in the task, because their essence is to coexist with each other, so that if there is a common goal to be carried out together so that social jealousy does not occur with each other. 


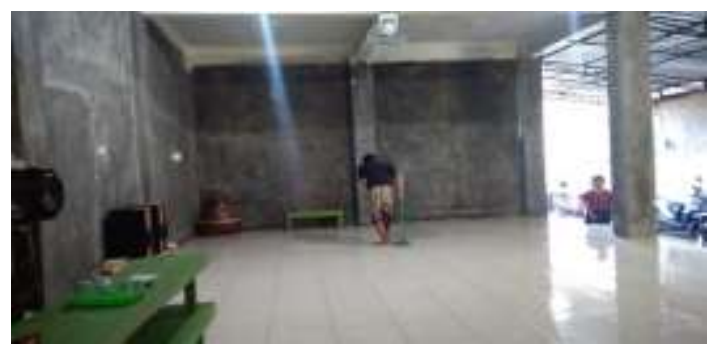

Fig. 1. Santri was cleaning the mushola of Islamic boarding school.

In ro'an activities, if there is santri who has not completed her/his assignments, other santri will help. Ro'an activities became a habit that had been used by the santri before and had been maintained until now. In essence, the ro'an goal is for all santri to be disciplined and care about themselves and their surroundings.

Although simple, ro'an is truly beneficial for the Islamic boarding school and for the santri themselves. With this routine activity, it is hoped that it can also have a positive impact on the life of the santri later after graduating from the Islamic boarding school. Santri is able to live a life of discipline, mutual cooperation and solidarity between friends. So that character education on environmental care will be embedded in a santri, even the tradition can foster a spirit of mutual cooperation and very good help to be used for their future provision if it has plunged into the real world of society.

\section{Conclusion}

With the various kinds of roans mentioned above, santri who carry out the tradition of roan will be sensitive to environmental cleanliness, always take care of the environment and avoid the desire to damage the environment around us. The caregivers at the Miftahu Rahmatillah Islamic Boarding School are as the motivator who always advises the santri to always take care of the environment, while the administrators are the regulator of the tradition of the ro'an to run well. While all santri are the executors of the ro'an tradition itself.

Habits of maintaining cleanliness of the environment certainly can work well thanks to encouragement in the form of adequate facilities from the boarding school in the form of cleaning tools such as (lawn mowers, hoes, machetes, wc brushes, soap, super mops, glass cleaning tools and so on ) It was very helpful in the process of running the ro'an tradition.

\section{References}

[1] Sani, Ridwan Abdullah: Pendidikan Karakter di Pesantren. Bandung : Cipta Pustaka Media Perintis. (2015)

[2] Wicaksono, Herman: "Integrasi Pendidikan Pesantren dan Sekolah dalam Prespektif Abdurrahman Wahid" Educreative, Volume 1, Nomor 2, (2016)

[3] Octavia, Lanny dkk: Pendidikan Karakter Berbasis Tradisi Pesantren. Jakarta: Rumah Kitab (2014) 